\title{
Optimal diet strategy of a large-bodied psittacine: food resource abundance and nutritional content enable facultative dietary specialization by the Military Macaw
}

\author{
Sylvia Margarita de la Parra-Martínez ${ }^{1}$, Luis Guillermo Muñoz-Lacy², Alejandro Salinas-Melgoza ${ }^{3}$
} and Katherine Renton ${ }^{4 *}$ (I)

\begin{abstract}
Background: Dietary specialization should arise when there is a relatively high abundance of a particular resource, where animals may select food items to obtain an optimal diet that maximizes energy intake. Large-bodied psittacines frequently exhibit a narrow dietary niche with specific habitat use, but few studies have determined whether psittacines select food resources, and how this influences habitat use.

Methods: We established fruiting phenology transects to evaluate food resource availability for the large-bodied Military Macaw (Ara militaris) in semi-deciduous, deciduous, and pine-oak forest at two sites along the coast of Jalisco, during the dry season when macaws are nesting. We also determined Military Macaw diet by observations of foraging macaws along transect routes, and conducted bromatological analysis of the nutritional content of the most consumed resource.

Results: Military Macaws used six plant species as food items during the dry season, and had a narrow dietary niche (Levins' $B=0.28$ ), with $56 \%$ of foraging macaws consuming the seeds of Hura polyandra. No food resources were recorded in pine-oak forest during the dry season, with food resources and foraging by macaws concentrated in tropical deciduous and semi-deciduous forest, where H. polyandra was the most abundant fruiting tree species. When considering the proportional availability of food resources, we determined a broad Hurlbert dietary niche breadth of $H=0.67$, indicating that Military Macaws consumed food resources according to their availability. Furthermore, the seeds of H. polyandra were an important source of protein, carbohydrates, minerals and moisture, and the hard fruitcasing means that these seeds are exclusively available for macaws.
\end{abstract}

Conclusions: By concentrating their diet on the most abundant resources, Military Macaws may increase foraging efficiency in the dry season. The high nutrient content also means that concentrating the diet on seeds of H. polyandra may be an optimal foraging strategy for Military Macaws to meet their energy requirements during the breeding season.

Keywords: Ara militaris, Bromatological analysis, Diet composition, Food resource selection, Fruiting phenology, Hura polyandra, Psittacidae, Tropical dry forest

*Correspondence: krenton@ib.unam.mx

${ }^{4}$ Estación de Biología Chamela, Instituto de Biología, Universidad

Nacional Autónoma de México, Apartado Postal 21, San Patricio-Melaque,

Jalisco, Mexico

Full list of author information is available at the end of the article

(c) The Author(s) 2019. This article is distributed under the terms of the Creative Commons Attribution 4.0 International License (http://creativecommons.org/licenses/by/4.0/), which permits unrestricted use, distribution, and reproduction in any medium, provided you give appropriate credit to the original author(s) and the source, provide a link to the Creative Commons license, and indicate if changes were made. The Creative Commons Public Domain Dedication waiver (http://creativecommons.org/ publicdomain/zero/1.0/) applies to the data made available in this article, unless otherwise stated. 


\section{Background}

Optimal foraging theory predicts that animals should forage in the most efficient manner to maximize fitness (MacArthur and Pianka 1966; Krebs and Davies 1984). One aspect of this is the selection of an optimal diet, where animals select food items in the diet to maximize energy intake (Pyke et al. 1997). In this sense, animals may feed on the most abundant resource, or in areas with a high abundance of resources (Charnov 1976; Martin 1985). Furthermore, a high abundance of one resource relative to other resources is likely to lead to dietary specialization (Schoener 1971; Pyke et al. 1997). Therefore, food specialization may be determined by the relative abundance of food resources, as well as metabolic, behavioural, and nutritional aspects of resource use (Stephens and Krebs 1986).

Psittaciformes (parrots) have been reported to consume a variety of plant species in the diet (Renton et al. 2015); although foraging may be concentrated on a few resources giving a narrow dietary niche (Renton 2001, 2006; Matuzak et al. 2008). In particular, large-bodied psittacines exhibit a narrow dietary niche with specific habitat use (Ragusa-Netto and Fecchio 2006; Matuzak et al. 2008). These large-bodied parrot species tend to consume a greater proportion of seeds in the diet (Matuzak et al. 2008), and have the capacity to consume both hard and soft fruits (Galetti 1997).

Large macaws consume an average of 15 plant species in the diet (range 4-48 plant species), although many studies report that macaws concentrate foraging on just 1-3 tree or palm species (Pitter and Christiansen 1995; López-Lanús 1999; Bonadie and Bacon 2000; RagusaNetto 2006; Renton 2006; Matuzak et al. 2008; Contreras-González et al. 2009; Santos and Ragusa-Netto 2014). Only a few studies have evaluated the proportional use of food resources by macaws, and these have determined a narrow dietary niche of Levins' $B=0.12-0.39$ for various species of large macaws (Ragusa-Netto 2006; Renton 2006; Matuzak et al. 2008; Contreras-González et al. 2009; Santos and Ragusa-Netto 2014). Therefore, large macaws may present specialized diets concentrated on the seeds of only a few plant resources, but it is unclear whether these also represent the most abundant food items.

Few studies have evaluated food resource selection by parrots in the wild (Renton et al. 2015), although some parrot species have been found to adjust dietary niche with fluctuations in food resource abundance (Renton 2001; Matuzak et al. 2008; Boyes and Perrin 2009a; Botero-Delgadillo et al. 2010), and the Ouvea Parakeet (Eunymphicus uvaeensis) selects in the diet plant species that have relatively constant fruit abundance throughout the year (Robinet et al. 2003). Food resource abundance is also one of the main factors influencing habitat use by birds (Block and Brennan 1993), and parrots have been shown to demonstrate habitat shifts in association with food resource abundance enabling them to track food resource availability (Greene 1998; Renton 2001).

Resource requirements is one of the least known aspects of psittacine ecology (Renton et al. 2015), and such information may indicate the characteristics making some species more vulnerable to human pressures, while other species are able to adapt to human modified habitats (Saunders and Ingram 1987; Saunders 1990, 1991). This is especially important for Psittaciformes, which is one of the most threatened avian families (Bennett and Owens 1997; Olah et al. 2016).

The Military Macaw (Ara militaris) is the most northerly distributed macaw occurring from Mexico to northern South America (Forshaw 1989). Little is known of Military Macaw diet, although the species may have a narrow dietary niche (Contreras-González et al. 2009), and appears to concentrate the diet on specific plant resources in the distinct geographic areas of its range (Juárez et al. 2012). The Military Macaw also demonstrates fluctuations in abundance among habitat types in association with variations in food resource availability (Morales-Pérez 2005; Muñoz-Lacy 2014). Timing of nesting by the Military Macaw varies notably in different regions of the species' range in Mexico (Juárez et al. 2012), which could be due to regional variations in temperature and precipitation that affect food resource availability.

On the coast of Jalisco, Military Macaws initiate nesting in late November to December, with chick rearing occurring during the dry season months of January to April (Carreon-Arroyo 1997). During this period, the Military Macaw was observed foraging mainly in trees of Hura polyandra (Loza-Salas 1997), suggesting that this tree species provides important resources for macaw reproduction. However, it is not known whether the Military Macaw exhibits dietary selection by specializing on specific food resources during the breeding season, how this relates to resource abundance, and whether this influences habitat use by macaws. Therefore, we aimed to determine (1) the composition of Military Macaw diets and proportional use of resources during the breeding season, (2) the nutritional content of the most consumed resource, (3) whether the Military Macaw exhibits food resource selection based on the relative abundance of resources, and (4) how food resource abundance influences habitat used for foraging. 


\section{Methods}

\section{Study site}

We conducted the study during the Military Macaw breeding season in the dry season months of March to April 2013 at two sites along the northern coast of Jalisco, Mexico. The first site known as Cajón de Peñas $\left(19^{\circ} 59^{\prime} 24^{\prime \prime}\right.$ to $20^{\circ} 02^{\prime} 54^{\prime \prime} \mathrm{N}$, and $105^{\circ} 01^{\prime} 30^{\prime \prime}$ to $105^{\circ} 07^{\prime} 12^{\prime \prime} \mathrm{W}$ ) is located in the Tomatlan Municipality, and the second site El Tuito $\left(20^{\circ} 16^{\prime} 12^{\prime \prime}\right.$ to $20^{\circ} 29^{\prime} 24^{\prime \prime} \mathrm{N}$, and $105^{\circ} 24^{\prime} 54^{\prime \prime}$ to $\left.105^{\circ} 40^{\prime} 12^{\prime \prime} \mathrm{W}\right)$ is located in Cabo Corrientes Municipality on the coast of Jalisco. The northern coast of Jalisco has an annual rainfall of 1624-2500 mm (García-Oliva et al. 1991), with mean yearly temperature of $24.6-28{ }^{\circ} \mathrm{C}$ (Sandoval 1992; SIEG 2012). There is a marked rainy season from June to October, followed by a dry season from November to May. The region has mountainous terrain from sea-level to $1920 \mathrm{~m}$ (SIEG 2012). The main vegetation at the study sites was semi-deciduous forest dominated by Brosimiun alicastrum, Enterolobium cyclocarpum, Hura polyandra, and Sabal mexicana, and deciduous forest dominated by Bursera instabilis, Spondius purpurea, Heliocarpus pallidus, Cochlospermum vitifolium and Guazuma ulmifolia (Rzedowski 2006). Pine-oak forest also occurred on higher terrain, and was dominated by Quercus glauscens, Curatella americana and Encyclia trachycarpa (Rzedowski 2006).

\section{Food resource availability}

We established a total of 22 phenology transects of $200 \mathrm{~m} \times 4 \mathrm{~m}$ (Chapman et al. 1994), distributed among three vegetation types, with nine transects in deciduous forest, eight in semi-deciduous forest, and five in pine-oak forest. Transects were surveyed during March and April 2013 in the dry season, recording all fruiting trees with a diameter at breast height $(\mathrm{DBH})>10 \mathrm{~cm}$. For each fruiting tree we measured $\mathrm{DBH}$ and estimated fruit abundance on the tree using a ranking scale of categories ranging from 1-4 based on the percent of canopy with fruits (Bullock and Solís-Magallanes 1990), where $1=$ up to $25 \%$ of canopy with fruits, $2=25 \%$ to $50 \%$ fruit cover, $3=50 \%$ to $75 \%$ fruit cover, and $4=75 \%$ to $100 \%$ of the canopy with fruit. We also classified fruits based on color as immature, mature or dried. We used four estimators of resource availability for each transect: (1) the number of tree species fruiting, (2) total number of fruiting trees, (3) the sum of DBH of fruiting trees, and (4) sum of the fruit abundance ranking for trees in each transect.

\section{Military Macaw diet}

The use of food resources in the diet was determined by direct observations of foraging macaws. Feeding observations were performed in the same area and at the same time as the phenology transects, including occasional adhoc observations while conducting field work. On encountering foraging macaws, we recorded the location, habitat type, plant species, plant part consumed, stage of ripeness, and number of macaws foraging. To determine dietary niche we considered the number of macaws observed foraging on each food item. However, to determine habitat use we considered the frequency of foraging records, or feeding bouts, of macaws (single or group) on each tree species (Galetti 1993).

\section{Nutritional analysis}

We collected fruits at the stage of ripeness in which they are consumed by macaws, from three trees of Hura polyandra at Cajon de Peñas. Fruits were maintained in refrigeration and taken for bromatological analysis of nutritional content of the seeds at the Animal Nutrition Laboratory of the Facultad de Medicina, Veterinaria y Zootecnia at the Universidad Nacional Autónoma de México (UNAM). The white seed kernel was extracted and analyzed to determine percent crude protein, lipids, fiber, ash, and humidity (Cunniff 1995). Mineral concentration of magnesium $(\mathrm{Mg})$, sodium $(\mathrm{Na})$, iron $(\mathrm{Fe})$, potassium $(\mathrm{K})$ and calcium $(\mathrm{Ca})$ was also determined using an Atomic Absorption Spectrophotometer (Skoog et al. 2008).

\section{Data analysis}

To determine dietary specialization in use of food resources by the Military Macaw, we calculated dietary niche breadth using the standardized Levins niche breadth index (Levins 1968; Krebs 1989), where a value close to 0 indicates dietary specialization and a value close to 1 indicates a broad diet (Colwell and Futuyma 1971). To determine selection of resources based on availability, we applied the Hurlbert (1978) index of niche breadth that estimates dietary niche considering the proportional use of each food resource with respect to the proportional availability of that resource. In this case, a value close to 0 indicates the selection of resources with limited availability in the environment, while a value close to 1 indicates that resources are being used according to their availability. We compared proportional use and availability of each item in the diet of Military Macaws using simultaneous Bonferroni 95\% confidence intervals (Neu et al. 1974; Byers et al. 1984).

We used data from the phenology transects to determine food resource abundance and availability for Military Macaws by habitat. We defined food resources available to Military Macaws based on our field observations of foraging macaws, and considered as potential food resources tree species that are consumed by Military Macaws throughout the species' distribution (Juárez et al. 2012), as well as tree species consumed by 
other macaw species (Vaughan et al. 2006; Renton 2006; Berg et al. 2007), where these occurred at our study sites (Loza-Salas 1997; Morales-Pérez 2005). During the survey period, we recorded no fruiting trees consumed by macaws in pine-oak forest; therefore, we only compared food resource availability between tropical deciduous and semi-deciduous forest, where we registered fruiting trees. Kolmogorov-Smirnov analysis demonstrated a normal distribution for the variables of number of fruiting trees, sum of DBH of fruiting trees, and sum of fruit abundance ranking per transect. Therefore, we applied two-sample $t$-tests to compare each estimator of food resource availability for Military Macaws between deciduous and semideciduous forest.

Finally, we used Chi square test to determine whether frequency of foraging by Military Macaws corresponded with that expected based on the number of fruiting trees that provide food resources for macaws in each habitat. Descriptive statistics are presented with mean and standard deviation, and we considered $p<0.05$ as significant for statistical analyses.

\section{Results}

Habitat-wide food resource abundance and availability

In the 22 phenology transects, we recorded a total of 193 fruiting trees of 24 species from 20 families that could provide food resources for macaws. Only nine tree species recorded more than $5 \%$ of all fruiting individuals in transects, with Hura polyandra (19\% of fruiting trees) being the most abundant fruiting tree species (Fig. 1). No food resources for Military Macaws were recorded in pine-oak forest during the months of March and April in the macaw breeding season. For tropical deciduous and semi-deciduous forest, food resource availability for Military Macaws was generally greater in semi-deciduous forest (Table 1), but this was only significant for sum of DBH of fruiting trees (Table 1). In general, we recorded different tree species in each forest type. However, six tree species were recorded fruiting in both deciduous and semi-deciduous forest: Hura polyandra, Annona palmeri, Enterolobium cyclocarpum, Bursera simaruba, Ficus spp., and Orbignya guacuyule, the first four of which were among the most abundant fruiting trees in transects

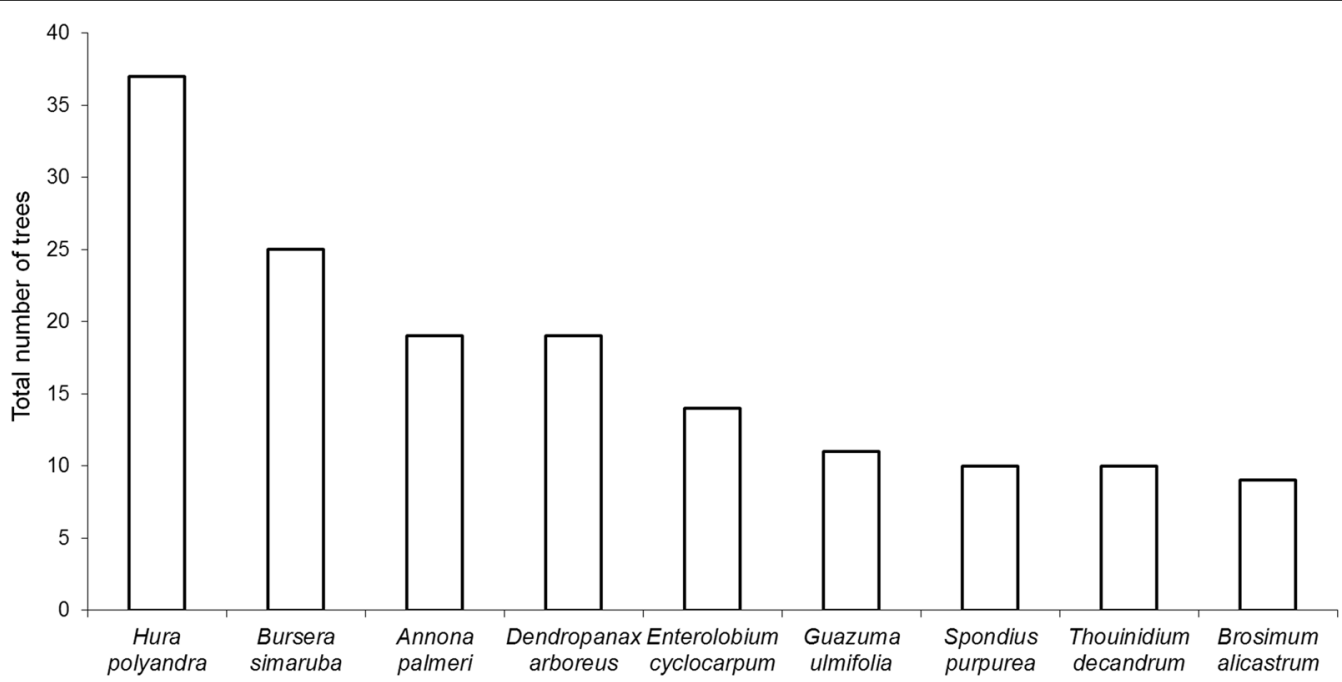

Fig. 1 Total abundance of fruiting tree species recorded in phenology transects that potentially provide food resources for Military Macaws (only species that represent $>5 \%$ of fruiting trees in phenology transects are shown)

Table 1 Mean ( \pm SD) per transect for estimators of food resource availability for Military Macaws in tropical deciduous and semi-deciduous forest at two sites along the coast of Jalisco in the dry season

\begin{tabular}{lccc}
\hline Variable & Deciduous & Semi-deciduous & Significance value \\
\hline Tree species fruiting & $5.7 \pm 1.7$ & $5.5 \pm 2.2$ & $t_{15}=0.17, \mathrm{~ns}$ \\
Number of fruiting trees & $9.3 \pm 5.2$ & $14.3 \pm 6.8$ & $t_{15}=1.65, \mathrm{~ns}$ \\
Sum of DBH of fruiting trees & $259.3 \pm 197.5$ & $444.3 \pm 136.3$ & $t_{15}=2.26, p<0.03$ \\
Sum of fruit abundance ranking & $16.3 \pm 6.4$ & $20.0 \pm 20.5$ & $t_{15}=0.49, \mathrm{~ns}$ \\
\hline
\end{tabular}

Two-sample $t$ test significance values are shown. No resources were recorded in pine-oak forest, therefore this habitat was excluded from analysis 
Table 2 Dietary items consumed by the Military Macaw during the dry season months of March and April 2013, at two sites along the coast of Jalisco

\begin{tabular}{lllc}
\hline Species (family) & Plant part consumed & Number of records & Total macaws \\
\hline Hura polyandra (Euphorbiaceae) & Immature seed & 22 & 48 \\
Brosimum alicastrum (Moraceae) & Immature and mature seed & 11 & 26 \\
Orbignya guacuyule (Palmae) & Mesocarp & 2 & 3 \\
Eugenia capuli (Myrtaceae) & Whole fruit & 1 & 2 \\
Anthurium halmoorei (Araceae) & Stem & 1 & 2 \\
Bursera simaruba (Burseraceae) & Immature seed & & 5 \\
\hline
\end{tabular}

Table 3 Mean ( \pm SD) nutritional content of unripe seeds of Hura polyandra from three trees at Cajon de Peñas, Jalisco, Mexico

\begin{tabular}{lc}
\hline Parameter & Composition \\
\hline Percent nutritional content (\%) & \\
Crude protein & $23.3 \pm 3.3$ \\
Crude fat & $27.5 \pm 5.4$ \\
Ash & $3 \pm 0.2$ \\
Crude fibre & $3.5 \pm 0.8$ \\
Moisture & $35.6 \pm 6.5$ \\
Mineral composition (mg/kg) & \\
Magnesium (Mg) & $54.1 \pm 24.9$ \\
Sodium (Na) & $8.8 \pm 19.3$ \\
Potassium (K) & $44 \pm 23.7$ \\
Iron (He) & $0.7 \pm 0.18$ \\
Calcium (Ca) & $0.95 \pm 0.05$ \\
\hline
\end{tabular}

(Fig. 1), contributing to the similarity in food resource availability between these two tropical forest vegetation types.

\section{Military Macaw diet}

We observed the Military Macaw consuming six food resources during the dry season when macaws were nesting. Seeds were the main component of the diet, although macaws also consumed fruits of Eugenia capuli, the mesocarp of Orbignya guacuyule fruits, and leaf stems of the epiphyte Anthurium halmoorei. Military Macaws presented a narrow dietary niche during the dry season with Levins' $B=0.289$, indicating a specialized diet, where the main food item was immature seeds of Hura polyandra consumed by $56 \%$ of foraging macaws, followed by seeds of Brosimum alicastrum, although these were consumed by only $30 \%$ of individuals (Table 2 ).

Bromatological analysis of the main item in macaw diets demonstrated that unripe seeds of Hura polyandra have a high percent of crude protein, lipids, and humidity (Table 3). Mineral analysis also found a high

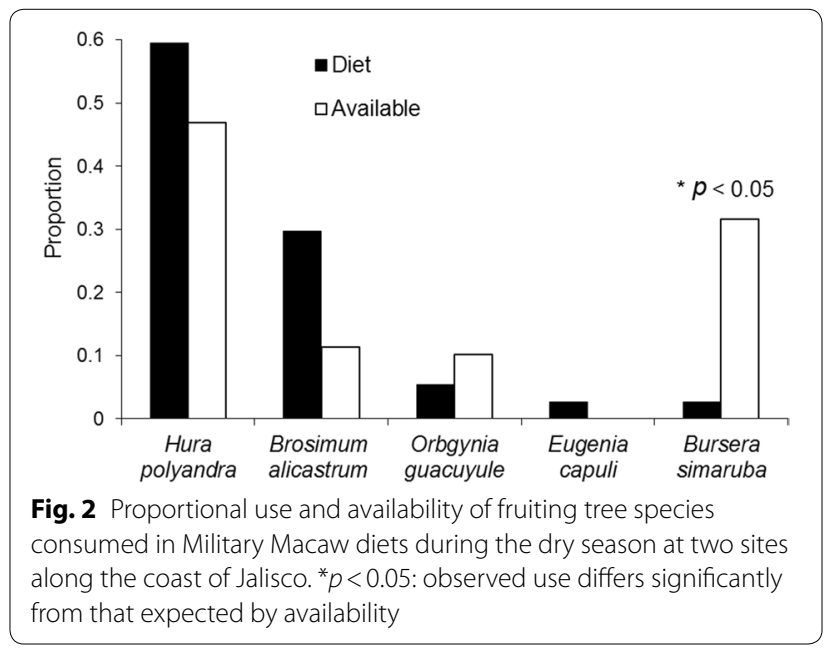

concentration of Magnesium and Potassium in seeds of Hura polyandra (Table 3).

Food resource selection by Military Macaws

When we evaluated whether Military Macaws selected food items consumed in the diet, we obtained a broad Hurlbert dietary niche of $H=0.674$. This indicates that the Military Macaw consumed resources in the diet according to their proportional abundance (Fig. 2). Hence, although Military Macaws consumed predominantly seeds of Hura polyandra, this was the most abundant food resource for macaws (Fig. 2). Comparison of proportional use and availability of each item in the Military Macaw diet, using simultaneous Bonferroni 95\% confidence intervals, showed that only in the case of Bursera simaruba seeds of this tree species were consumed by Military Macaws significantly less than expected by the availability of fruiting trees (Observed proportion $=0.03$, Confidence Intervals: 0-0.10, Expected proportion $=0.32$; Fig. 2).

Finally, we recorded Military Macaws foraging more frequently in semi-deciduous forest $(n=27$ records) 
compared to deciduous forest (12 records). Semi-deciduous forest also had a greater number of 126 fruiting trees compared to 67 fruiting trees in deciduous forest, and the frequency of foraging by macaws was similar to that expected based on the number of fruiting trees in each habitat type $\left(x^{2}=0.27, n s\right)$.

\section{Discussion}

\section{Diet and food resource selection by Military Macaws}

The Military Macaw consumed predominantly immature seeds, as has been determined for other large parrot species (Galetti 1993; Gilardi 1996; Renton 2001, 2006; Matuzak et al. 2008; Gilardi and Toft 2012). The use of seed resources may be in part influenced by the nutritional quality of food resources as seeds are higher in protein and lipids than other plant parts (Gilardi and Toft 2012). Hence, a predominantly seed diet may enable large macaws to more efficiently meet their daily energy requirements, as larger bird species require greater amounts of protein for body maintenance and growth (Klasing 1998; Koutsos et al. 2001). This may be of greater relevance during the breeding season when protein content is essential both for adult maintenance and for nestling growth (Koutsos et al. 2001).

Furthermore, even though we recorded 24 fruiting tree species that could potentially provide food resources for macaws at the study sites, the Military Macaw exhibited a specialized diet during the dry season when macaws are nesting, with a narrow dietary niche concentrated on the seeds of only a few plant resources. Studies of a variety of macaw species have determined that they exhibit narrow dietary niche breadths, concentrated on 1-3 tree species (Ragusa-Netto 2006; Renton 2006; Matuzak et al. 2008; Contreras-González et al. 2009; Santos and Ragusa-Netto 2014). This differs from smaller parrot species that have a broad dietary niche (Matuzak et al. 2008; Boyes and Perrin 2009b).

In particular, the Military Macaw concentrated foraging on immature seeds of Hura polyandra, which was the most abundant food resource available for macaws. Lozas-Salas (1997) also noted that Military Macaws at the Cajon de Peñas study site consumed predominantly seeds of $H$. polyandra. Furthermore, we determined that the seeds of $H$. polyandra were high in protein and lipid content, and percent protein in seeds of $H$. polyandra was similar to that found for seed oil of the related species H. crepitans (Okolie et al. 2012; Abdulkadir et al. 2013). Seeds of $H$. polyandra also had high mineral concentrations, particularly of magnesium and potassium, similar to that found in seed oil of H. crepitans (Okolie et al. 2012; Abdulkadir et al. 2013), although iron, which is one of the high concentration minerals in seed oil of $H$. crepitans (Okolie et al. 2012; Abdulkadir et al. 2013), had very low concentration in unripe seeds of $H$. polyandra. Finally, in contrast with seed oil of $H$. crepitans (Okolie et al. 2012; Abdulkadir et al. 2013), the unripe seeds of $H$. polyandra had high moisture content. This makes the seeds of $H$. polyandra a valuable source of protein, energy, minerals and water during the dry season when Military Macaws are raising young.

The next frequently consumed item of Brosimum alicastrum has been found to contain lower $15.4 \%$ to $15.9 \%$ crude protein (Plata et al. 2009; Montes-Pérez et al. 2012). Similarly, while Bursera simaruba was the second most abundant fruiting tree species, seeds of this tree species were consumed by Military Macaws significantly less than expected, and have been found to contain a low $12.4 \%$ crude protein (Plata et al. 2009). Large parrot species require at least $10-15 \%$ protein for maintenance, and require $>20 \%$ protein for nestling growth (Koutsos et al. 2001). The lower protein content in the seeds of Brosimum alicastrum and Bursera simaruba may explain why they are consumed less frequently by Military Macaws during the breeding season when macaws are raising young.

Therefore, seeds of Hura polyandra represent an abundant and highly nutritious food resource, which may enable greater dietary specialization by the Military Macaw during the breeding season. The use of food resources with a high protein and lipid content may permit consumers to obtain their nutrient requirements from just a few resources. The European Serin (Serinus serinus) exhibits a similar dietary specialization on the seeds of Diplotaxis virgata during the breeding season, which was accounted for by the high protein and energy content of the seeds, rather than food resource availability (Valera et al. 2005). The Glossy Black-Cockatoo (Calyptorhynchus lathami) in Australia also has a specialized diet consuming the seeds of two species of Allocasuarina trees, which have very high $43.5 \%$ protein and $38 \%$ lipid content (Crowley and Garnett 2001).

However, seeds also have high levels of toxicity (Gilardi and Toft 2012), and seeds of Hura polyandra are extremely toxic (López-Bazán 2002). No other bird species were observed to consume seeds of $H$. polyandra, possibly due to the thick, hard capsule protecting seeds, and their toxicity. The absence of competitors makes this a potentially exclusive, highly nutritious food resource for Military Macaws, which along with the high abundance of $H$. polyandra at the study sites, would facilitate dietary specialization (Schoener 1971; Pyke et al. 1997).

Moreover, the broad Hurlbert niche breadth indicates that the Military Macaw consumed food resources according to their availability. Hence, although the Military Macaw consumed predominantly the seeds of Hura polyandra, this was the most abundant food resource 
during the dry season. Indeed, $H$. polyandra has been determined as the main food resource for Military Macaws in the dry season by different studies at this site over a span of 20 years (Loza-Salas 1997; Morales-Perez 2005; Muñoz-Lacy 2014). This suggests that abundant fruiting of $H$. polyandra, and resource consumption by macaws, is an annually repeated pattern at this site, and makes the seeds of $H$. polyandra a reliable food resource for nesting macaws. Concentrating the diet on the most abundant resources, that may also provide high energy intake, could be the most efficient foraging strategy for macaws, and highlights the importance of considering both food resource availability and nutritional value when evaluating dietary requirements.

\section{Habitat-wide food resource availability}

During the Military Macaw breeding season on the coast of Jalisco, we registered food resources for macaws only in lowland tropical semi-deciduous and deciduous forests, with a tendency for higher food resource availability in semi-deciduous forest. Military Macaws were recorded foraging in both forest types, but with greater frequency in semi-deciduous forest, as expected by the number of fruiting trees. This may be due to the fact that the main item of macaw diets, Hura polyandra, was the most abundant fruiting tree species, and occurred in both forest types at the study site. Foraging where there are more fruiting trees may enable the Military Macaw to forage more efficiently, rather than expend energy searching for new resource patches. Finally, we found no food resources available for Military Macaws in pine-oak forest during our study, although Military Macaws have been reported to consume seeds and fruits of Oak trees (Juárez et al. 2012).

It is possible that food resource availability is not the main factor influencing habitat use by the Military Macaw during the breeding season, given that macaws did not demonstrate food resource selection, but consumed mainly the most abundant resources. On the other hand, Military Macaws are highly selective of nestsites using cavities in large, mature trees characteristic of primary semi-deciduous forest, which occur at a low density (de la Parra-Martínez et al. 2015). Therefore, availability of nest-sites may define the use of specific habitats or areas by macaws during the breeding season, with macaws exploiting the most abundant food resource available in those areas.

The characteristics of the Military Macaw as a large psittacine species that concentrates the diet on only a few food resources during the breeding season, and with highly selective nest-site requirements (de la Parra-Martínez et al. 2015), makes the species more susceptible to habitat loss, or the decline of key food resources. Hura polyandra is a tree species characteristic of semi-deciduous forests (Pennington and Sarukhan 2005), which are undergoing high rates of conversion and fragmentation in Mexico (de Jong et al. 2010). The potential reduced availability or loss of a key food resource such as $H$. polyandra as a result of habitat fragmentation may have consequences for reproductive output of the Military Macaw, and the maintenance of wild populations. Military Macaws have been extirpated from previous parts of their range in Mexico as semi-deciduous forests become increasingly fragmented. It is important therefore to implement conservation strategies to maintain semideciduous forest habitats required by macaws for nesting (de la Parra-Martínez et al. 2015), and tree species such as $H$. polyandra that constitutes a key food resource for Military Macaws in the dry season when macaws are raising young.

\section{Conclusions}

Our results determined that the Military Macaw had a narrow dietary niche during the dry season, concentrating the diet on the most abundant tree species of Hura polyandra that also provided seeds with high nutrient content. The reliability and abundance of fruiting, as well as its high nutritional content, suggests that $H$. polyandra is a key food resource for Military Macaws during the breeding season. $H$. polyandra is distributed throughout the range of the Military Macaw in Mexico (Pennington and Sarukhan 2005). Therefore, it may be that $H$. polyandra is an important food resource during the breeding season of the Military Macaw in other areas of the species' range. Notably, the Military Macaw has been observed consuming seeds of $H$. polyandra during the breeding season in Sinaloa (Rubio 2015) and Nayarit (Puebla-Olivares et al. 2018) in Mexico, while $H$. crepitans is reported in the diet of the Military Macaw in South America (Juárez et al. 2012). Moreover, the Military Macaw has been found to concentrate the diet on one or a few specific plant resources in distinct geographic areas of its range (Juárez et al. 2012). It may be therefore, that the Military Macaw is a facultative dietary specialist, concentrating the diet on the most abundant, nutritious resource, to increase foraging efficiency and energy intake for adult survival and reproductive success.

\footnotetext{
Acknowledgements

Nutritional analyses were conducted by the Laboratorio de Nutrición Animal of the Facultad de Medicina, Veterinaria y Zootecnia, UNAM, and we are grateful to Águeda García Pérez for assistance with bromotological analyses. We are grateful to the Cajon de Peñas local community for permission to work on their lands, and thank Bonnie Jauregui for logistical support.
}

\section{Authors' contributions}

KR conceived and designed the study. SMdP-M, LGM-L, and AS-M conducted field work and collected data. SMdP-M, and KR analysed and interpreted the data. SMdP-M and KR wrote and revised the paper. KR contributed reagents/ 
materials/analysis tools, and obtained funding. All authors read and approved the final manuscript.

\section{Funding}

The research was funded by UNAM-DGAPA-PAPIIT Grant IN205716, the Consejo Nacional de Ciencia y Tecnología (MX) project 179877, and the Loro Parque Fundación A.C., all to KR. The Consejo Nacional de Ciencia y Tecnología (MX) provided study grants (Doctoral Grant 220278 to SMdP-M, Postdoctoral Grant 98294 to AS-M, and Masters student grant to LGM-L). SMdP-M also received a Graduation Bonus from the Posgrado en Ciencias Biológicas.

\section{Availability of data and materials}

The data supporting conclusions of this article are included within the manuscript.

\section{Ethics approval and consent to participate}

All procedures and protocols comply with Mexican law, and the Dirección General de Vida Silvestre of the Secretaria del Medio Ambiente y Recursos Naturales provided permits for the research.

\section{Consent for publication}

Not applicable.

\section{Competing interests}

The authors declare that they have no competing interests.

\section{Author details}

1 Departamento de Ciencias Biológicas, Centro Universitario de la Costa, Universidad de Guadalajara, Av. Universidad No. 203, Delegación Ixtapa, C.P. 48280 Puerto Vallarta, Jalisco, Mexico. ${ }^{2}$ Comisión Nacional Para el Conocimiento y Uso para la Biodiversidad, Liga Periférico-Insurgentes Sur 4903, Delegación Tlalpan, 14010 Mexico City, Mexico. ${ }^{3}$ Facultad de Biología, Universidad Michoacana de San Nicolás de Hidalgo, Ciudad Universitaria, Morelia, Michoacán, Mexico. ${ }^{4}$ Estación de Biología Chamela, Instituto de Biología, Universidad Nacional Autónoma de México, Apartado Postal 21, San Patricio-Melaque, Jalisco, Mexico.

Received: 4 July 2018 Accepted: 17 September 2019 Published online: 14 October 2019

\section{References}

Abdulkadir MN, Isiaka AA, Adeniyi OA. Chemical composition of Hura crepitans seeds and antimicrobial activities of its oil. Int I Sci Res (Ahmedabad). 2013;2:440-5.

Bennett PM, Owens IPF. Variation in extinction risk among birds: chance or evolutionary predisposition? Proc R Soc Lond B. 1997;264:401-8.

Berg KS, Socola J, Angel RR. Great Green Macaws and the annual cycle of their food plants in Ecuador. J Field Ornithol. 2007;78:1-10.

Block WM, Brennan LA. The habitat concept in ornithology: theory and applications. Curr Ornithol. 1993;11:35-91.

Bonadie WA, Bacon PR. Year-round utilisation of fragmented palm swamp forest by Red-bellied Macaws (Ara manilata) and Orange-winged parrots (Amazona amazonica) in the Nariva Swamp (Trinidad). Biol Conserv. 2000;95:1-5.

Botero-Delgadillo E, Verhelst JC, Paéz CA. Ecología de forrajeo del periquito de Santa Marta (Pyrrhurra viridicata) en la Cuchilla de San Lorenzo, Sierra Nevada de Santa Marta. Ornitol Neotrop. 2010;21:463-77.

Boyes RS, Perrin RM. The feeding ecology of Meyer's Parrot Poicephalus meyeri in the Okavango Delta Botswana. Ostrich. 2009a;80:153-64.

Boyes RS, Perrin RM. Generalists, specialists and opportunists: niche metrics of Poicephalus parrots in southern Africa. Ostrich. 2009b;80:93-7.

Bullock SH, Solís-Magallanes J. Phenology of canopy trees of a tropical deciduous forest in Mexico. Biotropica. 1990;22:22-35.

Byers CR, Steinhorst RK, Krausman PR. Clarification of a technique for analysis of utilization-availability data. J Wild Manage. 1984;48:1050-3.

Carreón-Arroyo G. Estimación poblacional, biología reproductiva y ecología de la nidificación de la Guacamaya Verde (Ara militaris) en una selva estacional del oeste del estado de Jalisco. B.Sc. Thesis. Mexico City: Facultad de Ciencias, Universidad Nacional Autónoma de México; 1997.
Charnov EL. Optimal foraging, the marginal value theorem. Theor Popul Biol. 1976;9:129-36.

Chapman CA, Wrangham R, Chapman LJ. Indices of habitat-wide fruit abundance in tropical forests. Biotropica. 1994;26:160-71.

Colwell RK, Futuyma DJ. On the measurement of niche breadth and overlap. Ecology. 1971;52:567-76.

Contreras-González AM, Rivera-Ortíz FA, Soberanes-González C, Valiente-Banuet A, Arizmendi MC. Feeding ecology of Military Macaws (Ara militaris) in a semi-arid region of Central Mexico. Wilson J Ornithol. 2009;121:384-91.

Crowley GM, Garnett ST. Food value and tree selection by Glossy Black-Cockatoos Calyptorhynchus lathami. Austral Ecol. 2001;26:116-26.

Cunniff P. Official methods of analysis of AOAC International. 16th ed. Arlington: AOAC International; 1995.

De Jong B, Anaya C, Masera O, Olguín M, Paz F, Etchevers J, et al. Greenhouse gas emissions between 1993 and 2002 from land-use change and forestry in Mexico. Forest Ecol Manag. 2010;260:1689-701.

de la Parra-Martínez SM, Renton K, Salinas-Melgoza A, Muñoz-Lacy LG. Treecavity availability and selection by a large-bodied secondary cavitynester: the Military Macaw. J Ornithol. 2015;156:489-98.

Forshaw JM. Parrots of the world. 3rd ed. Willoughby: Landsdown Editions; 1989.

Galetti M. Diet of the Scaly-headed Parrot (Pionus maximiliani) in a semi-deciduous forest in southeastern Brazil. Biotropica. 1993;25:419-25.

Galetti M. Seasonal abundance and feeding ecology of parrots and parakeets in a lowland Atlantic forest of Brazil. Ararajuba. 1997;5:115-26.

García-Oliva F, Ezcurra E, Galicia L. Pattern of rainfall distribution in the central Pacific coast of Mexico. Geogr Ann A. 1991;73:179-86.

Gilardi JD. Ecology of parrots in the Peruvian Amazon: habitat use, nutrition and geophagy. Ph.D Thesis. Davis: University of California; 1996.

Gilardi JD, Toft CA. Parrots eat nutritious foods despite toxins. PLOS ONE. 2012;7:e38293.

Greene TC. Foraging ecology of the Red-crowned Parakeet (Cyanoramphus novaezelandiae novaezelandiae) and Yellow-crowned Parakeet (C. auriceps auriceps) on Little Barrier Island, Hauraki Gulf, New Zealand. N Z J Ecol. 1998;22:161-71.

Hurlbert SH. The measurement of niche overlap and some relatives. Ecology. 1978;59:67-77.

Juárez M, Marateo G, Grilli PG, Pagano L, Rumi M, Silva-Croome M. Estado del conocimiento y nuevos aportes sobre la historia natural del guacamaya verde (Ara militaris). Hornero. 2012;27:5-16.

Klasing KC. Comparative avian nutrition. Wallingford: CAB International; 1998. Krebs CJ. Ecological methodology. New York: Harper and Row; 1989.

Koutsos EA, Matson KD, Klasing KC. Nutrition of birds in the order Psittaciformes: a review. J Avian Med Surg. 2001;15:257-75.

Krebs JR, Davies NB. Behavioural ecology: an evolutionary approach. 2nd ed. Malden: Blackwell Scientific Publications; 1984.

Levins R. Evolution in changing environments. Princeton: Princeton University Press; 1968.

López-Bazán TF. Envenenamiento con semillas de Hura polyandra (haba de San Ignacio). Rev Mex Med Urg. 2002;2:61-4

López-Lanús B. The biology of Great Green Macaw Ara ambigua in southwest Ecuador. Papageienkunde. 1999;3:147-69.

Loza-Salas CA. Patrones de abundancia, uso de hábitat y alimentación de la guacamaya verde (Ara militaris), en la presa Cajón de Pena, Jalisco, Mexico. B.Sc Thesis. Mexico City: Facultad de Ciencias, Universidad Nacional Autónoma de México; 1997.

MacArthur RH, Pianka ER. On optimal use of a patchy environment. Am Nat. 1966;100:603-9.

Martin TE. Resource selection by tropical frugivorous birds: integrating multiple interactions. Oecologia. 1985;66:563-73.

Matuzak GD, Bezy MB, Brightsmith DJ. Foraging ecology of parrots in a modified landscape: seasonal trends and introduced species. Wilson J Ornithol. 2008;120:353-65.

Montes-Pérez RC, Mora Camacho O, Mukul Yerves JM. Forage intake of the Collared Peccary (Pecari tajacu). Rev Colomb Cienc Pecu. 2012;25:586-91.

Morales-Pérez L. Evaluación de la abundancia poblacional y recursos alimenticios para tres géneros de psitácidos en hábitats conservados y perturbados de la costa de Jalisco México. M.Sc Thesis. Mexico City: Universidad Nacional Autónoma de México; 2005.

Muñoz-Lacy LG. Uso del hábitat y recursos alimenticios por la guacamaya verde (Ara militaris) en la costa de Jalisco y su potencial para el 
ecoturismo. M.Sc. Thesis, Mexico City: Universidad Nacional Autónoma de México; 2014

Neu CW, Byers CR, Peek JM. A technique for analysis of utilization-availability data. J Wildl Manage. 1974;38:541-5.

Okolie PN, Uaboi-Egbenni PO, Ajekwene AE. Extraction and quality evaluation of Sandbox Tree seed (Hura crepitan) Oil. World J Agric Sci. 2012;8:359-65.

Olah G, Butchart SHM, Symes A, Medina Guzman I, Cunningham R, Brightsmith DJ, et al. Ecological and socio-economic factors affecting extinction risk in parrots. Biodivers Conserv. 2016:25:205-23.

Pennington TD, Sarukhán J. Árboles tropicales de México. Manual para la identificación de las principales especies. 3rd ed. Mexico City: Universidad Nacional Autónoma de México y Fondo de Cultura Económica; 2005.

Pitter E, Christiansen MB. Ecology, status and conservation of the Red-fronted Macaw Ara rubrogenys. Bird Conserv Int. 1995;5:61-78.

Plata FX, Evergenny S, Resendiz JL, Villarreal O, Bárcena R, Viccon JA, et al. Palatabilidad y composición química de alimentos consumidos en cautiverio por el venado cola blanca de Yucatán (Odocoileus virginianus yucatanensis). Arch Med Vet. 2009;41:123-9.

Puebla-Olivares F, Salcedo-Hernandez JE, Figueroa-Esquivel EM. El habillo (Hura polyandra) en la dieta de la guacamaya verde (Ara militaris). Huitzil Rev Mex Ornitol. 2018;19:157-67.

Pyke GH, Pulliam HR, Charnov EL. Optimal foraging: a selective review of theory and tests. Q Rev Biol. 1997;52:137-54.

Ragusa-Netto J. Dry fruits and the abundance of the Blue-and-yellow Macaw (Ara ararauna) at a cerrado remnant in central Brazil. Ornitol Neotrop. 2006;17:491-500.

Ragusa-Netto J, Fecchio A. Plant food resources and the diet of a parrot community in a gallery forest of the Southern Pantanal (Brazil). Braz J Biol. 2006;66:1021-32.

Renton K. Lilac-crowned parrot diet and food resource availability: resource tracking by a parrot seed predator. Condor. 2001;103:62-9.

Renton K. Diet of adult and nestling Scarlet Macaws in Southwest Belize, Central America. Biotropica. 2006;38:280-3.

Renton K, Salinas-Melgoza A, De Labra Hernández MA, de la Parra-Martínez SM. Resource requirements of parrots: nest-site selectivity and dietary plasticity of Psittaciformes. J Ornithol. 2015;156(Suppl. 1):73-90.

Robinet O, Bretagnolle V, Clout M. Activity patterns, habitat use, foraging behavior and food selection of the Ouvea Parakeet (Eunymphicus cornutus uvaeensis). Emu. 2003;103:71-80.
Rubio RY. Preferencia de hábitat de la guacamaya verde (Ara militaris Linné) en el municipio de Cosalá, Sinaloa. M.Sc. Thesis. Mexico City: Universidad Nacional Autónoma de México; 2015.

Rzedowski J. Vegetación de México, digital edition. Comisión Nacional para el Conocimiento y Uso de la Biodiversidad, Mexico City; 2006. http://www. biodiversidad.gob.mx/publicaciones/librosDig/pdf/NegetacionMx_Cont. pdf.

Sandoval GMP. Inventario avifaunístico de la presa Cajón de Peña, Jalisco, México. Guadalajara: Universidad Autónoma de Guadalajara; 1992.

Santos AA, Ragusa-Netto J. Plant food resources exploited by Blue-and-Yellow Macaws (Ara ararauna, Linnaeus 1758) at an urban area in Central Brazil. Braz J Biol. 2014;74:429-37.

Saunders DA. Problems of survival in an extensively cultivated landscape: the case of Carnaby's Cockatoo Calyptorhynchus funereus latirostris. Biol Conserv. 1990;54:277-90.

Saunders DA. The effect of land clearing on the ecology of Carnaby's Cockatoo and the inland Red-tailed Black Cockatoo in the wheatbelt of western Australia. Acta XX Congressus International Ornithologici; 1991. p 658-65.

Saunders DA, Lngram JA. Factors affecting survival of breeding populations of Carnaby's Cockatoo Calyptorhynchus funereus latirostris in remnants of native vegetation. In: Saunders DA, Arnold GW, Burbidge AA, Hopkins AJM, editors. Nature Conservation: the role of remnants of native vegetation. Australia: Surrey Beatty \& Sons; 1987. p. 249-58.

Schoener TW. Theory of feeding strategies. Ann Rev Ecol Syst. 1971;2:369-404.

SIEG. Diagnóstico del Municipio Cabo Corrientes. Sistema de Información Estadística y Geográfica de Jalisco. 2012. http://iieg.gob.mx/contenido/ Municipios/cuadernillos/Cabocorrientes.pdf.

Skoog DA, Holler FJ, Crouch SR. Principios de análisis instrumental. 6th ed. Illes Balears: Cengage Learning; 2008.

Stephens DW, Krebs JR. Foraging theory. Princeton: Princeton University Press; 1986.

Valera F, Wagner RH, Romero-Pujante M, Gutiérrez JE, Rey PJ. Dietary specialization on high protein seeds by adult and nestling serins. Condor. 2005;107:29-40.

Vaughan CN, Nemeth N, Marineros L. Scarlet Macaw, Ara macao, (Psittaciformes: Psittacidae) diet in central Pacific Costa Rica. R Biol Trop. 2006;54:919-26.
Ready to submit your research? Choose BMC and benefit from:

- fast, convenient online submission

- thorough peer review by experienced researchers in your field

- rapid publication on acceptance

- support for research data, including large and complex data types

- gold Open Access which fosters wider collaboration and increased citations

- maximum visibility for your research: over $100 \mathrm{M}$ website views per year

At BMC, research is always in progress.

Learn more biomedcentral.com/submissions 